\title{
Measuring Teachers' Job Satisfaction: A Locale and Gender Based Comparison of Secondary School Teachers
}

\author{
Shama Batool ${ }^{1}$ \\ Dr. Muhammad Tahir Khan Farooqi ${ }^{2}$ \\ Dr. Mobeen U1 Islam ${ }^{3}$
}

\begin{abstract}
The research study is an effort to determine the influence of secondary school teachers' gender and location on their job satisfaction in Pakistani perspective. The target population of the study was all secondary school teachers (SSTs) serving in public secondary schools of Punjab Province whereas accessible population was all secondary school teachers (2084 SSTs) serving in 456 public secondary schools of Sahiwal division. The Sahiwal division is comprised of three districts viz. Pakpattan, Sahiwal and Okara. From each district, 24 schools (12 male and 12 female) were randomly selected and from each school 4 SSTs were taken randomly as sample. In this way total sample was consisted of 288 SSTs. The data were collected through Job Satisfaction Scale for Teachers (JSST). The collected data were tabulated and analyzed through SPSS. The analysis revealed that rural teachers were more satisfied from jobs rather than urban teachers and male teachers were more satisfied with their supervisors and working conditions rather than their female counterparts. The study recommended that urban secondary school heads and female secondary school heads may provide opportunities to get more exposure on supervision. Class size in urban secondary schools may be reduced to enhance urban secondary school heads' job satisfaction level.
\end{abstract}

Keywords: Job Satisfaction, Locale, Gender, Secondary School Teachers

\section{Introduction}

Teachers belong to the community of employees who have to perform in different conditions and have to face higher level of stress in comparison to any other typical organization human resource (Klassen \& Chiu, 2010). Unlike that typical organizations' workforce teachers have to perform multiple tasks as to educate children, maintenance of healthy and safe environment, collaboration

\footnotetext{
${ }^{1}$ MPhil Scholar, University of Education Lahore (Okara Campus) Email: Shamabatool786@gmail.com

${ }^{2}$ Assistant Professor, Department of Education, University of Okara, Okara, Email: drtahirkhanfarooqi@gmail.com

${ }^{3}$ Assistant Professor, Department of Education, University of Gujrat, Gujrat, Email: drmobeen.islam@uog.edu.pk
} 
with parents, specialists and top management, development of their own skills, documentary work, arrangements of study tours and trips and a wide range of duties entrusted by government or school administration (Comber \& Nixon, 2009). Often they have to teach problematic students and have to meet arbitraries parents. These interactions demand well communication, problem solving, and conflict management skills to handle these situations. These challenging situations demand emotional stability and intellectual integrity from teachers' side; otherwise, they may face dissatisfaction from their jobs (Chang, 2009).

The concept of job satisfaction has universal meanings as it includes certain aspects of job which hinder or enhance individual level of job gratification. These may be included financial benefits, ordinates and subordinates relationships, working environment and promotion opportunities. Overall orientation of these factors is appraised as job satisfaction (Alnajjar,1996). It is evident from above exposition that the meaning of job satisfaction is employees' attitude towards their job and it is the name of reward after struggle, doing job well and feelings of pleasure at work site. Job satisfaction is core ingredient that leads towards promotion, acknowledgement and attainment of objectives. This concept is closely associated with motivation because motivated employees are more satisfied.

Pay, work, working conditions, promotion, supervision, colleagues, social benefits, security, gender equality, demographic location, recognition and appreciation are some aspects which cause teachers job satisfaction levels (Spector, 1997). Obtaining and retention of quality teachers is greatest concern for educational managers today. There is consensus among educationists that teachers' retention is only possible if they are satisfied from their jobs. So, the present study is an exertion of the researchers to compare the job satisfaction of rural and urban, male and female secondary school teachers in Punjab.

\subsection{Objectives of the Study}

The objectives of the study included to;

1. determine relationship between rural and urban secondary school teachers' job satisfaction level.

2. determine relationship between male and female secondary school teachers' job satisfaction level.

\subsection{Hypotheses}

$\mathrm{H}_{0} 1$ There is no significant relationship between rural and urban secondary school teachers' job satisfaction level.

$\mathrm{H}_{0} 2$ There is no significant relationship between male and female secondary school teachers' job satisfaction level. 


\section{Review of Literature}

Williams and Anderson (1991) consider job satisfaction as employees' feelings regarding their jobs and their different assigned duties at job. It is also the level of people gratification and dissatisfaction about their jobs. Monyatsi (2012) examines job satisfaction as favorable, delightful and satisfied state of mind which someone seeks from his job. Myer, Conte, and Peterson (2007) explain that it is the extent of employee's delight or gratification which he attains from his job. Gratified employee, therefore, takes extra interest in his duties, shows regularity and affiliation with his organization, while a dissatisfied worker suits for new organizations and feels stress at job. Quarstein, McAfee and Glassman (1992) associate job satisfaction with situational variables and happenings. On the contrary, Spector (1997) views job satisfaction in two extremes; organizational environment in which employees find transactions, appreciation, fulfillment and gratification and conversely an environment of dissatisfaction, frustration and stress.

Judge and Klinger (2008) interpret that job satisfaction is consistent with one's enrichment of mind with his/her job values that are associated with his needs. According to Bogler (2001) job satisfaction is influenced by two types of factors, intrinsic factors (autonomy, reorganization, prestige and giving worth to employees) and extrinsic factors (pay package, rewards and working conditions). Extrinsic and intrinsic both factors are valued for job satisfaction. The major cause of exit from teaching profession of teachers are their neglecting salaries (Ingersoll, 2001; Page \& Page, 1982). Fair compensation is the major cause of teachers' satisfaction but there is not heed towards it. Cascio (1987) considers that according to equity theory if employees are not well compensated there is not solution except to leave the profession. While, Locke (1969) argues that pay is an economic support and a mean of satisfaction for workers. When employees are paid adequately it makes them satisfied and committed towards the organization.

Work itself determines the gratification level of an employee from his job. Gormley (2003) states that employees' individuality should also be recognized at workplace and they must be given stimulation because workers prefer a job that is less tedious, less challenging and provide opportunities for self-actualization. Promotion brings positive results in employees' attitude and they feel more confidant, autonomous and gratified (Gormley, 2003). Obineli (2013) states that promotion is linked with social prestige of workers and it indirectly relates to job satisfaction because when workers' salaries are increased they are able to fulfill their increasing needs. On the other side, researchers like Hoy and Miskel (1996) 
suggest that too early promotion of top achievers creates dissatisfaction and despair among experienced and loyal workers.

Teachers' job satisfaction is also effected by cooperation and interaction among colleagues on work (Miller, 2006). The working place is like a mini society where mutual relations and attitudes of workers and better understanding and cooperation among workers boost their job satisfaction level (Piccolo \& Colquitt, 2006). Menon and Christou (2002) are of the view that cooperation and mutual respect among workers and supervisors results in higher job satisfaction among employees.

Working environment with all necessary facilities is a milestone towards the job satisfaction among teachers and stimulating working place (Charlesworth \& Crozier 2003). Vischer (2007) asserts that comfortable physical working environment influences employees' job satisfaction. Temperature, humidity, working hours, hygiene and all other physical conditions all made working conditions and absence of these will provoke negativity among workers (Kabir \& Parvin, 2011).

Appreciation and positive relationship between head teacher and teachers can affect job satisfaction of employees. If head teacher provides feedback and focus on quality instead of quantity during his supervision, it enhances employees' morale and confidence (Bell \& Menguc, 2002). Teachers usually complain favoritism and inequalities from head teachers therefore. they feel deprivation and a sense of ignorance from their administrators. It creates feelings of dissatisfaction among teachers (Miller, 2006). If employees are supervised and treated fairly, their job satisfaction level enhances and if they feel that their supervisors are incompetent and unfair with them, their job satisfaction level will decline (Piccolo \& Colquitt, 2006).

\section{Research Methodology}

Survey technique was opted via using Job Satisfaction Scale for Teachers (JSST) as measuring instrument.

\subsection{Population of Study}

The population of the study was consisted of public sector secondary schools (male \& female) situated in 9 divisions (36 districts) of the Punjab Province. The study was delimited to Sahiwal Division only (three districts; Pakpattan, Okara and Sahiwal) due to lack of time and financial resources. Accessible population of the study was 2084 secondary school teachers serving in 456 public secondary schools of Sahiwal Division. 


\subsection{Sample and Sampling Technique}

The researchers used stratified random sampling technique to select 24 (12 male \& 12 female) secondary schools from each district. In this way, the whole sample was comprised of 288 male and, female public secondary schools of Sahiwal Division. The following table represents a glimpse of sample of the study.

Table: 1 District Wise Selected Sample of Secondary School Teachers

\begin{tabular}{|c|c|c|c|c|c|c|c|c|c|c|}
\hline \multirow{3}{*}{ Districts } & \multicolumn{5}{|c|}{ Schools } & \multicolumn{5}{|c|}{ Teachers } \\
\hline & \multicolumn{2}{|c|}{ M } & \multicolumn{2}{|c|}{$\mathrm{F}$} & \multirow{2}{*}{$\mathrm{T}$} & \multicolumn{2}{|c|}{$\mathrm{M}$} & \multicolumn{2}{|c|}{$\mathrm{F}$} & \multirow{2}{*}{$\mathrm{T}$} \\
\hline & $\mathrm{R}$ & $\mathrm{U}$ & $\mathrm{R}$ & $\mathrm{U}$ & & $\mathrm{R}$ & $\mathrm{U}$ & $\mathrm{R}$ & $\mathrm{U}$ & \\
\hline Okara & 6 & 6 & 6 & 6 & 24 & 24 & 24 & 24 & 24 & 96 \\
\hline Sahiwal & 6 & 6 & 6 & 6 & 24 & 24 & 24 & 24 & 24 & 96 \\
\hline Pakpattan & 6 & 6 & 6 & 6 & 24 & 24 & 24 & 24 & 24 & 96 \\
\hline Total & 18 & 18 & 18 & 18 & 72 & 72 & 72 & 72 & 72 & 288 \\
\hline
\end{tabular}

The above table shows that 72 schools were selected by the researcher from 3 districts of Sahiwal Division and from each school 4 SSTs were taken as respondents, so the sample size was 288 secondary school teachers working in public secondary schools.

\subsection{Instrument of the Study}

Job Satisfaction Scale for Teachers (JSST) developed by Mehrotra (2005) and adapted by Iqbal (2010) was used to administer survey for the present study. It is a Likert type close ended instrument and consisted of 60 items having 6 factors related to job satisfaction. They were: pay, work, promotion, working group, working conditions, and supervision. Consent was taken from the developer of JSST and then it was implemented. Before implementation, the questionnaire was pilot tested. Cronbach Alpha reliability coefficient of the questionnaire was found 0.78 . It showed consistency of opinion of respondents.

\subsection{Data Collection}

Data were personally collected by the researchers themselves. Researchers visited the selected secondary school teachers regarding data collection. They were informed about the purpose of research and consent was sought from them. Printed instructions were provided to respondents to fill in the questionnaires. Reason of provision of printed instructions was to minimize the biased feedback. Completed questionnaires were again collected by the researchers personally after two weeks of delivering the questionnaires. In this way data were collected efficiently and ensured $100 \%$ response rate. 


\section{Data Analysis}

Data were analyzed by applying Independent Sample t-test using Statistical Package for Social Sciences (SPSS) version 19.

$\mathrm{H}_{0} 1$ : There is no significant relationship between rural and urban secondary school teachers' job satisfaction level.

Table: 2 Rural and Urban Teachers' Job Satisfaction at Secondary Level

\begin{tabular}{cccccc}
\hline Respondents & $\mathrm{N}$ & Mean & S.D & r & p-value \\
\hline Rural & 144 & 3.36 & .215 & \multirow{2}{*}{.516} & \multirow{2}{*}{$.002^{* *}$} \\
Urban & 144 & 3.29 & .195 & & \\
\hline
\end{tabular}

**Correlation is significant at the 0.01 level (2-tailed).

Table 2 showed that there exist a significant correlation between rural and urban teachers job satisfaction level $(\mathrm{t}-\mathrm{value}=.516, \mathrm{p}=0.002<0.01)$. Hence the null hypothesis that, "there is no significant relationship between rural and urban secondary school teachers' job satisfaction" is rejected. Therefore, it is concluded that there is significant and strong relationship of job satisfaction between the teachers of rural and urban areas.

$\mathrm{H}_{0} 2$ There is no significant relationship between male and female secondary school teachers' job satisfaction level.

Table: 3 Job Satisfaction Levels between Male and Female Teachers at Secondary Level

\begin{tabular}{cccccc}
\hline Respondent & $\mathrm{N}$ & Mean & S.D & r & p-value \\
\hline Male & 144 & 3.36 & .206 & \multirow{2}{*}{195} & \multirow{2}{*}{$.004^{* *}$} \\
Female & 144 & 3.29 & .204 & & \\
\hline
\end{tabular}

**Correlation is significant at the 0.01 level (2-tailed).

Table 3 indicates that there is significant correlation between male and female teachers' job satisfaction level $(\mathrm{r}=.195$, $\mathrm{p}$-value $=0.004<0.01)$. Hence the null hypothesis that, "there is no significant relationship between male and female secondary school teachers' job satisfaction" is rejected. It is therefore concluded that there is significant relationship in the job satisfaction level of male and female teachers is present.

\section{Findings}

1. When the comparison between rural and urban secondary school teachers' job satisfaction was examined, it was inferred from findings that there exist a strong significant and positive relationship between rural and urban teachers job satisfaction level $(\mathrm{r}=.516, \mathrm{p}=0.002<0.01)$.

2. The comparison between rural and urban teachers' job satisfaction level in secondary schools was analyzed. It was revealed from findings there is week 
and significant difference is present between male and female teachers' job satisfaction level $(\mathrm{r}=.195$, $\mathrm{p}$-value $=0.004<0.01)$.

\section{Discussion}

Results of the study on comparing secondary school teachers' job satisfaction showed significant difference between rural and urban teachers. Rural teachers were found more satisfied as compared to urban teachers for pay, work, work group and supervision dimensions of job satisfaction. The results of the study are contrary to the research conducted by Iqbal and Akhtar (2012). In another research study conducted by Wang, Lin and Liang (2017), rural school teachers' job satisfaction level was found more than that of urban school teachers. Results of this study supported the results of present study. Rural school teachers showed more satisfaction on pay, work, work group and supervision as compared to urban secondary school teachers.

Another finding of the study showed significant and moderate difference of secondary school teachers' job satisfaction between male and female teachers. Male secondary school teachers reflected more satisfaction on promotion and supervision than female secondary school teachers. Results of the study are similar to the results of the study conducted by Lambert, Hogan, Barton \& Lubbock (2001) and Al-Mashaan (2003) but are contrary to the results reported by Iqbal and Akhtar (2012) and Bhat (2018).

\section{Conclusions}

Rural and urban worksites had a significant and positive relationship with secondary school teachers' job satisfaction. It showed that rural secondary school teachers were found more satisfied from their jobs as compared to urban secondary school teachers. It also revealed that secondary school teachers' locale affects on their job satisfaction. Similarly, positive and significant correlation was found between male and female teachers' job satisfaction level. It was found that male secondary school teachers are more satisfied from their job as compared to female secondary school teachers. Male secondary school teachers were more satisfied with their supervisors and working conditions.

\section{Recommendations}

Based on findings and conclusions, following recommendations were made;

1. Location wise, rural teachers were more satisfied from their jobs as the needs of rural teachers are less than urban teachers. Allocating big city allowance and double salaries for double shift schools in big cities can improve the job satisfaction of urban secondary school teachers.

1. There is dire need to work on social interaction among urban secondary school teachers. Large class size affects the job satisfaction level of urban 
secondary school teachers. It is very necessary to induct more teachers in urban public schools to minimize the class size consequently job satisfaction may increase. Rural secondary school teachers are found more interactive and had positive relationship with their teachers as compared to urban secondary school teachers. Urban secondary school Heads may be trained on this component.

2. Besides, the study manifested that male teachers were more satisfied with their jobs. It might be justified because male dominated workplaces are friendlier and less restrictive. They find enough spare time to earn their livelihood through other sources; therefore, they are more satisfied. On the other hand females are more status conscious and find dissatisfaction from low salaries. Offering scholarships, education loans, stipends and effective supervisory system for female teachers can enhance their satisfaction level. Female head teachers may be trained on supervision for effective supervision of their subordinates.

\section{References}

Al-Mashaan, O. (2003). Associations among job satisfaction, pessimism, and psychosomatic symptoms of employees in the government sector. Psychological Reports, 93, 17-25.

Alnajjar, A. A. (1996). Relationship between job satisfaction and organizational commitment among employees in the United Arab Emirates. Psychological Reports, 79(1), 315-321.

Bell, S. J., \& Menguc, B. (2002). The employee-organization relationship, organizational citizenship behaviors, and superior service quality. Journal of retailing, 78(2), 131-146.

Bhat, A. A. (2018). Job Satisfaction among high school teachers. The International Journal of Indian Psychology, 6(1), 45-53.

Bogler, R. (2001).The influence of leadership style on teacher job satisfaction. Educational Administration Quarterly, 37(5), 662-683.

Cascio, W. F. (1987). Applied psychology in personnel management. Englewood Cliffs, NJ: Prentice-Hall. 
Chang, M. L. (2009). An appraisal perspective of teacher burnout: Examining the emotional work of teachers. Educational Psychology Review, 21, 193218.

Charlesworth, K., Cook, P., \& Crozier, G. (2003). Leading change in the public sector: Making the difference. London: Chartered Management Institute.

Comber, B., \& Nixon, H. (2009).Teachers' work and pedagogy in an area of accountability. Discourse: Studies in the Cultural Politics of Education, 30(3), 333-345.

Gormley, D. K. (2003). Factors affecting job satisfaction in nurse faculty: A meta-analysis. The Journal of Nursing Education, 42(4), 174-178.

Hoy, W. K., \& Miskel, C. G. (1996). Educational administration: Theory, research, and practice. McGraw Hill.

Ingersoll, R. M. (2001). Teacher turnover, teacher shortages, and the organization of schools.

Seattle, WA: Center for the Study of Teaching and Policy.

Iqbal, A. S. I. F. (2010). A Comparative Study of the Impact of Principals' Leadership Styles on Job Satisfaction of Teachers. (Unpublished Ph.D. Thesis). University of Punjab. Lahore, Pakistan.

Iqbal, A., \& Akhtar, S. (2012). Job satisfaction of secondary school teachers. Abasyn journal of social sciences, 5(1), 49-65.

Judge, T. A., \& Klinger, R. (2008). Job satisfaction: Subjective well-being at work. The science of subjective well-being, 393-413.

Kabir, M. N., \& Parvin, M. M. (2011). Factors affecting employee job satisfaction of pharmaceutical sector. Australian Journal of Business and Management Research, 1(9), 113-123.

Klassen, R. M., \& Chiu, M.M. (2010). Effects on teachers' self-efficacy and job satisfaction: Teacher gender, years of experience, and job stress. Journal of Educational Psychology, 102(3), 741-756. 
Lambert, E. G., Hogan, N. L., Barton, A., \& Lubbock, S. M. (2001). The impact of job satisfaction on turnover intent: A test of a structural measurement model using a national sample of workers. Social Science Journal, 38(2), 233-251.

Locke, E. A. (1969). What is job satisfaction? Organizational behavior and human performance, 4(4), 309-336.

Mehrotra, A. (2005). Leadership Styles of Principals. India: Mittal Publications, New Delhi.

Menon, M. E., \& Christou, C. (2002). Perceptions of future and current teachers on the organization of elementary schools: a dissonance approach to the investigation of job satisfaction. Educational Research, 44(1), 97-110.

Miller, W. R. (2006). Rethinking substance abuse: What the science shows and what we should do about it, Guilford Press.

Monyatsi, P. P. (2012). The level of job satisfaction of teachers in Botswana. European Journal of Educational Studies, 4(2), 219-232.

Myer, R. A., Conte, C., \& Peterson, S. E. (2007). Human impact issues for crisis management in organizations. Disaster Prevention and Management, 16(5), 761-770.

Obineli, A. S. (2013). Teachers' Perception of the Factors Affecting Job Satisfaction in Ekwusigo Local Government of Anambra State, Nigeria. African Research Review, 7(4), 225-237.

Page, F. M. Jr., \& Page J. A. (1982). Perceptions of teaching that may be influencing the current shortage of teachers. College Student Journal, 16, 308-311.

Piccolo, R. F., \& Colquitt, J. A. (2006). Transformational leadership and job behaviors: The mediating role of core job characteristics. Academy of Management Journal, 49(2), 327-340.

Quarstein, V. A., McAfee, R. B., \& Glassman, M. (1992). The situational occurrences theory of job satisfaction. Human Relations, 45(8), 859-873. 
Spector, P. E. (1997). Job satisfaction: Application, assessment, causes, and consequences (Vol. 3). Sage Publications.

Vischer, J. C. (2007). The effects of the physical environment on job performance: Towards a theoretical model of workspace stress. Stress and Health, 23(3), 175-184.

Wang, C. C., Lin, H. M., \& Liang, T. L. (2017). A Study on Comparing the Relationship among Organizational Commitment, Teachers' Job Satisfaction and Job Involvement of Schools with Urban-Rural Discrepancy. Educational Research and Reviews, 12(16), 762-771.

Williams, L. J., \& Anderson, S. E. (1991). Job satisfaction and organizational commitment as predictors of organizational citizenship and in-role behaviors. Journal of management, 17(3), 601-617. 